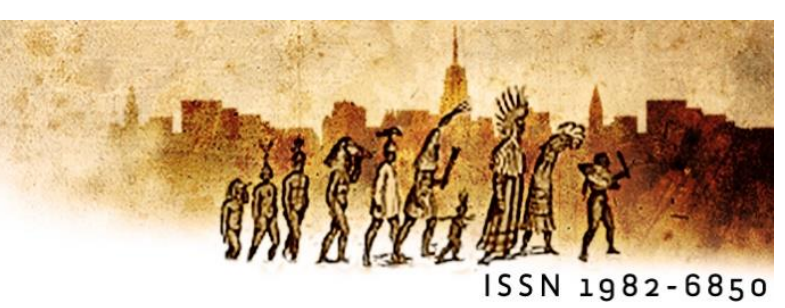

\title{
Intersubjetividade, metaficção, polifonia e intertextualidade em Elisa, vida mía, de Carlos Saura. O filme (1977) e o romance (2004)
}

\author{
Cristina Bongestab (UEPB) ${ }^{i}$ \\ José Alberto Miranda Poza (UFPE) ${ }^{i i}$
}

\begin{abstract}
Resumo:
Neste artigo desenvolvemos algumas reflexões a propósito do filme de Carlos Saura Elisa, vida mía (1977) que teve continuidade no romance, do mesmo título e autor em 2004. O fato de ter se produzido uma adaptação de diferente direção (filme-romance e não vice-versa) bem como as possíveis causas que, 27 anos depois, levaram Saura a revisitar sua criação artística nortearam nosso trabalho. Através de recursos intersemióticos, Saura recupera a memória individual/coletiva da Espanha através da memória individual dos personagens. Ao abordar a memória histórica, Saura traduz para a ficção a devastação pessoal e social que a política oficial procurou ocultar usando-se do recurso do flash-back, o que possibilitou uma adaptação do filme para o romance com alto grau de fidelidade. Através dele, Saura apresentou as indagações, dúvidas e angústias do passado dos protagonistas. Verificamos, ainda, que a metaficção funciona como instrumento de reconstrução do passado porque o cenário teatral funciona como metáfora visual dos seus arquivos: um espaço imaginário depositário de recordações, marcado aqui pela encenação do auto religioso El gran teatro del mundo, de Calderón de la Barca. O diálogo proposto por Saura se estende ainda a outros autores do Século de Ouro espanhol como Garcilaso de la Vega ou Baltasar Gracián. Isso nos conduz à intertextualidade e à polifonia (Bakthin, Kristeva, Genette). Nesse sentido, será mostrado como o filme (1977) e o romance (2004) foram escritos de maneira polifônica, entrelaçando a poesia, o teatro, a música e a fotografia, o qual conduz à consideração do caráter criativo multifacético de Saura.

Palavras-chave: Intersubjetividade. Metaficção. Polifonia. Intertextualidade. Carlos Saura.
\end{abstract}

\begin{abstract}
:
In this article we develop some reflections about the film of Carlos Saura Elisa, vida mía (1977) which was followed up in the novel, by the same title and author in 2004. The fact of having produced an adaptation of a different direction (film-novel and not the other way around) as well as the possible causes that, 27 years later, led Saura to revisit his artistic creation, guided our work. Through intersemiotic resources, Saura recovers the
\end{abstract}


individual / collective memory of Spain through the individual memory of the characters. In addressing the historical memory, Saura translates into fiction the personal and social devastation that official politics sought to conceal using the flash-back feature, which made it possible to adapt the film to the novel with a high degree of fidelity. Through it, Saura presented the inquiries, doubts and anguish of the protagonists' past. We further verify that metafiction functions as an instrument for the reconstruction of the past because the theatrical scenario functions as a visual metaphor for its archives: an imaginary space which is the depository of memories, enhanced here by the staging of the religious drama The Great Theater of the World by Calderón de la Barca. The dialogue proposed by Saura extends to other authors of the Spanish Golden Age such as Garcilaso de la Vega or Baltasar Gracián. This leads us to intertextuality and polyphony (Bakthin, Kristeva, Genette). In this sense, it will be shown how the film (1977) and the novel (2004) were written in a polyphonic way, interweaving poetry, theater, music and photography, which leads to the consideration of Saura's multifaceted creative character.

Keywords: Intersubjectivity. Metafiction. Polyphony. Intertextuality. Carlos Saura.

\section{Introdução}

Carlos Saura é um diretor de cinema e escritor multifacético, o que se verifica pelo fato de que em suas obras se entrelaçam literatura, pintura, dança, música, fotografia e teatro. Dentro deste universo, Saura escreveu e dirigiu uma gama de filmes nos quais é possível evidenciar uma forte conexão entre memória e melancolia. Entre os seus filmes mais estudados estão Ana y los lobos (1973); La Prima Angélica (1974); Cría cuervos (1976) e Mamá cumple cien años (1979). Elisa, vida mía, de 1977, recebeu, comparativamente aos filmes citados, muita menos atenção por parte dos estudiosos da obra de Saura. Nosso trabalho trata sobre este filme e sua posterior adaptação para romance porque, ao mesmo tempo em que ele se insere no cânone melancólico da cultura espanhola, ao refletir sobre a condição humana, trata da devastação pessoal e social advindas da Guerra Civil. Esses temas são mediados por um riquíssimo diálogo com a pintura, a música, a literatura e o cinema de Buñuel, Bergman e Fellini, sublinhando seu caráter polifônico e multifacético.

Nossa escolha se ampara ainda pela singularidade de Elisa, vida mía no processo de transposição filme/livro - Saura partiu do seu filme para a escritura do romance de mesmo nome. Geralmente essa adaptação acontece da maneira inversa: o romance é transformado em filme. A primeira pergunta que nos ocorreu foi por que Saura, depois de 
27 anos, teria resolvido transpor o filme Elisa, vida mía (1977) para a linguagem de romance, e a primeira resposta que nos ocorreu foi que Saura talvez tenha tido essa ideia porque escrevera o filme em um momento em que ainda havia repressão na Espanha e não podia assim se expressar livremente. Passados 27 anos, ele poderia então atualizar, explicitar e aprofundar os temas esboçados no filme - e ressalta a atemporalidade da angústia humana e os longevos efeitos do pós-guerra. Acreditamos também que a escolha da linguagem do romance tenha sido proposital, pois se a narrativa cinematográfica de Elisa, vida mía se centrava na subjetividade mediada por uma dimensão onírica, repleta de sonhos e alusões, a narrativa romanesca, despida de recursos cênicos, permitiria um mergulho mais profundo nos pensamentos melancólicos dos personagens.

Mesmo no romance, entretanto, Saura não renuncia completamente ao cinema, ao lançar mão de uma escrita intersemiótica, adotando técnicas representativas da linguagem pictórica - e da literatura, do teatro, da pintura, da fotografia e da música. Através dos recursos intersemióticos, Saura recupera a memória individual e coletiva, configurando-se aí a relevância do nosso estudo sobre memória na obra de Saura.

No âmbito da memória, o trauma e a história negada, consideramos que Elisa, vida mía, filme (1977) e romance (2004), são marcados pela reconstrução do passado e Saura revisita assim a memória coletiva/histórica da Espanha através da memória individual dos personagens. Ao abordar a memória histórica, Saura traduz para a ficção a devastação pessoal e social que a política oficial procurou ocultar. Para tanto, utilizaremos como subsídio teórico os autores Weinrich (2001) e Colmeiro (2005) para as contribuições sobre memória, e os autores Buades (2006) e Beevor (2007) para as contribuições sobre a visão do contexto histórico.

Destacamos que, apesar de não ser nosso objetivo priorizar o caráter autobiográfico da obra de Saura, não podemos deixar de considerar que Elisa, vida mía, especificamente, apresenta traços de autobiografia. Algumas cenas do filme e passagens do romance abordarão, na maioria das vezes de forma metafórica, a Guerra Civil espanhola, por isso não podemos deixar de mencionar que a infância de Carlos Saura foi marcada por essa guerra e que ela foi rememorada em muitas de suas obras.

\section{O Filme (1977) e o Romance (2004): Relações Intersubjetivas}


Para facilitar nossa análise sobre polifonia e intertextualidade, sintetizaremos, primeiramente, o filme (1977) e, posteriormente, o romance (2004), escrito por Saura 27 anos depois. Sobre esta relação intersemiótica de Saura (passagem da linguagem cinemática de Elisa, vida mía para a linguagem romanesca), tomamos emprestada a reflexão de Hammerschmitid sobre as relações intersemióticas na obra Lluvia amarilla (1988), de Julio Llamazares para apresentarmos nossa visão sobre essa relação em Saura, na incorporação do cinema pelo romance. Hammerschimitid (2008) esclarece que nesse romance de Llamazares, prevalece a escritura cinematográfica. Nele são narradas as recordações do último habitante de um povoado abandonado das montanhas leonesas, Ainiellle, que se negou a sair do seu habitat, morrendo depois de viver dez anos em solidão absoluta, somente interrompida por seu cachorro e pelos fantasmas de sua mãe, de sua esposa e de alguns vizinhos que voltavam dos túmulos para fazer-lhe companhia.O romance, de acordo com Hammerschimitid (2008), conta a agonia de protagonista, a partir do fluir da consciência de Andrés. O monólogo interior se perde entre os tempos de sua vida passada e sua morte futura. Andrés, no começo do romance, imagina sua morte, o que antecipa a visão do final: a chegada dos que vão encontrar seu cadáver descomposto. 0 romance se apresenta em forma de um flash-forward que inaugura um flash-back desordenado e elíptico.

Elisa, vida mía (filme e romance) contam a história de Luis, um professor universitário que abandona a família em Madri para viver com simplicidade e sem conforto em Melque, um pequeno povoado perto de Segóvia. Por vinte anos, Luis vive sozinho nesse povoado, dando aulas de literatura para crianças de um colégio de freiras e fazendo traduções. Elisa, que mora em Paris com o marido, vai visitar o pai que se encontra muito doente e resolve passar uma temporada com ele. Luis morre; Elisa decide continuar morando na mesma casa onde o pai morava e resolve assumir o seu lugar na escola. Ressaltamos que o livro e o filme são centrados nos personagens, suas vozes e seus conflitos, assim como Llamazares faz em La lluvia amarilla (1988). Também, como na obra de Llamazares, Elisa, vida mía, filme (1977) e romance (2004), são textos de ficção, construídos através de flashbacks que resgatam o passado. Saura utiliza esta técnica para mostrar as lembranças dos personagens.

\subsection{0 filme}


O roteiro do filme Elisa, vida mía foi escrito em 1977, pouco depois da morte de Franco, em 1975, período de transição entre a ditadura e a democracia, época em que ainda havia censura, motivo pelo qual Saura escreveu um texto no qual ainda não podia se expressar livremente. Situaríamos, assim, esta película dentro do conjunto de filmes metafóricos de Saura - as alegorias e metáforas ao mesmo tempo em que caracterizam recursos narrativos, servem para driblar a censura e ressaltar o impacto da Guerra Civil espanhola na população da Espanha. ${ }^{1}$

O filme começa com a imagem de um carro, em uma estrada de terra, chegando à casa de Luis, pai de Elisa e de Isabel. No carro estão Elisa, Isabel e o marido desta (Julián), e os dois filhos do casal, que vão visitar Luis para comemorar o aniversário dele. A voz do narrador, no começo do filme, é masculina (Luis), mas sob a ótica de Elisa, que conta que há muito não via o pai e que estava triste por que ia vê-lo doente.

A voz masculina conta que a doença do pai de Elisa, que era casada com Antonio e morava em Paris, havia coincidido com a crise no casamento dela. Ainda em Paris, Elisa, ao receber o telegrama da irmã sobre a doença do pai, percebe a gravidade da situação eresolve visitar o pai no dia do aniversário dele. Elisa explicita que a doença de Luis foi uma desculpa para afastar-se do marido e pensar na situação dela. ${ }^{2} \mathrm{~A}$ narração da voz masculina termina quando entram na casa de Luis.

Ele não se encontrava, tendo saído para o povoado. Enquanto esperam sua chegada, Elisa entra no escritório do pai e na mesa encontra os rascunhos de seu diário e o livro El Criticón, de Baltasar Gracián (1651-1657). Elisa lê o texto de Luis, com sua própria voz.3

\footnotetext{
${ }^{1}$ Ricoeur, no seu célebre ensaio sobre a metáfora (2001), estabelecia limites entre ela e a alegoria. A alegoria como a metáfora "apresentam um pensamento sob a imagem de outro, mais adequado para fazê-lo mais sensivel ou mais incisivo que se for apresentado diretamente e sem vê-lo" (apud MIRANDA POZA, 2014, p. 164). Ora, a alegoria se diferencia da metáfora por um grau especial de união com a proposição. Assim, a metáfora, inclusive continuada, apresenta apenas um sentido verdadeiro, o figurado, enquanto a alegoria "consiste em uma proposição de duplo sentido, literal e espiritual, ao mesmo tempo" (apud MIRANDA POZA, 2014, p. 164).

${ }^{2}$ Trecho da fala do filme: "Conforme ia me afastando de Antonio, percebia que não podia voltar mais para o homem com quem havia passado sete anos da minha vida" (SAURA, 1977).

${ }^{3}$ Trecho da fala do filme: "Minha fadiga é de alguém que não vai a lugar nenhum. Mas para onde eu estava indo? Qual era meu objetivo? Talvez fosse só uma ilusão. Não posso dizer que fui enganado... porque eu mesmo colaborei com esse engano. Apenas agora me dou conta... que essa pessoa que havia aprendido muitas coisas... embora a maioria fosse sem valor... mas que deram sentido à vida... chegou a um ponto em que essas coisas... deixaram de ser úteis. Agora esse homem que vejo no espelho... quer começar uma vida diferente... sem rejeitar o passado. Esse homem não tem nada. Nem juventude, nem beleza. Nem sente que
} 
Na velhice, e diante da doença, Luis admite o cansaço e a frustração de alguém que não chegou a lugar algum. Pretende começar uma vida nova, mas o medo de ser tarde demais o angustia. O personagem tem uma grave doença e pressente a morte próxima. $O$ medo de ser tarde demais para começar outra vida é o obstáculo contra o qual Luis não tem armas para lutar, ciente de sua doença incurável e seu pouco tempo de vida. Concluímos que as lembranças do passado, a tristeza do presente e a incerteza do futuro desencadeiam a melancolia do personagem.

Entendemos a mudança de foco na narração quando Elisa lê o texto de Luis com sua própria voz, como uma forma de mostrar que ela também passa pelo mesmo processo de busca pessoal. Assim como o pai, ela pretende começar uma nova vida, como verificaremos no decorrer das narrativas (filme e romance). O texto que destacamos na citação se aplicaria também a ela por esse motivo.

Na sequência do filme, durante a comemoração do aniversário de Luis, Elisa comenta que sonha sempre com um estranho fenômeno: a família está reunida na casa de Madri e as coisas são exatamente como eram antes: os mesmos quadros nas paredes, a mesma mesa, o mesmo aparador e sobre o aparador a bandeja de prata, como o jogo de chá também de prata. É um dia muito ensolarado e a luz entra pela janela de uma forma muito difícil de explicar. É uma luz muito forte e toda a prata reflete essa luz. Então ela tem a estranha sensação de que as coisas têm vida própria: o jogo de chá, as xícaras começam a vibrar, a tilintar e de repente Elisa olha para cima e o lustre de cristal também começa a vibrar e tudo começa a tremer e tilintar.

Terminada a comemoração do aniversário, a família se prepara para voltar a Madri e Luis convida Elisa para passar uns dias com ele. Ela hesita, em princípio, mas aceita.

Assim que a família sai, Elisa e o pai vão dar um passeio pelas redondezas da casa de Luis, que mora no interior de Segóvia, em um local bastante isolado. No caminho, Luis conta para Elisa que, perto de uma pedra, nas imediações de sua casa, havia encontrado o corpo de uma mulher, cujo episódio ficou conhecido como "o crime da viúva". Contou também que alguém havia colocado no lugar do crime uma pedra branca e flores de plástico, e que todo ano, na mesma data, essa pessoa limpava a pedra e trocava as flores.

encontrou a verdade... mas simplesmente acredita em outra gratificação... aquela que a vida proporciona. Esse homem não tem a segurança... para aproveitar as coisas que dizem que vêm com a idade. Esse homem que cambaleia em seu caminho... tem o objetivo de começar uma vida nova. E o único obstáculo em seu caminho... é o medo de já ser tarde demais" (SAURA, 1977).

Eutomia, Recife, 24(1): 32-59, Set. 2019 
Quando voltam para casa, Elisa, pensativa, se imagina no lugar da mulher assassinada. Em seguida, o narrador, novamente com voz masculina (Luis), fala das impressões de Elisa sobre o pai, impressões que Ana (mãe de Elisa) havia deixado sobre o pai (Luis). No final da cena, descobrimos que o texto está sendo escrito pelo pai de Elisa.4

Há momentos no filme em que os dois protagonistas parecem se fundir, transformando-se em um único personagem. O trecho que citamos acima apresenta uma dessas situações. Em princípio, aparece Elisa pensando no pai e como a imagem que dele tinha, através da parcialidade da mãe, estava mudando com a sua convivência com ele. Em seguida, aparece uma cena em que Luis está escrevendo exatamente o texto no qual Elisa estava pensando. Também poderíamos pensar nessa forma de narrar de Saura como se estivesse utilizando o recurso da metaficção: Luis como o autor e Elisa como personagem que representa o texto escrito pelo pai, que fala dele próprio, mas ao mesmo tempo fala dela, que também passava pelo mesmo processo de autoconhecimento.

A cena que segue é de Elisa, adulta, na casa de Luis em Segóvia, que, ao acordar, diz que não pode fazer barulho, que se fizer barulho perde o jogo. Assim, sai silenciosamente do quarto e abre uma porta, que já não é mais da casa de Segóvia e sim da sala da casa de Madri, onde passou a infância. Em uma espécie de sonho, vê a família reunida na sala, e, adulta, sorri para ela própria, criança. Nessa cena Saura mescla sonho e imaginação. Elisa acorda e já não está mais sonhando, mas aparentemente está, porque aparece em outro cenário, vendo-se como criança. Partindo do pressuposto de que o foco do filme está muito mais nos aspectos existenciais dos personagens do que na trama, Saura estaria representando a imaginação de Elisa no momento em que ela acorda. Concordamos com Avellar (1981), que afirma que a cena em que Elisa adulta encontra a Elisa menina nos apresenta um sentimento impossível de ser sentido sem o cinema. Para ele, essa cena representa um tipo de emoção especial que qualquer pessoa tem diante de uma foto antiga,

\footnotetext{
${ }^{4}$ Trecho da fala do filme: "A figura de meu pai agora se engrandece com o tempo. Agora entendo que a imagem que tinha dele... era através da parcialidade de minha mãe. No momento que compreendeu que ele não voltaria mais para casa... sutilmente, com a insistência de quem conhece a verdade... e quer convencer os outros... dedicou-se a demonstrar, para si mesma e para nós... que meu pai era um homem doente e egoísta. Sem dúvida minha mãe era a personalidade forte da família. Era voluntariosa e decidida, ainda que, às vezes, sofria de depressão. Dizia que estava mal e que queria morrer... e ficava uns dias na cama sem querer saber de nada. Acontecia algo estranho com ela, sem explicação concreta. Sentia-se vazia, inútil, insatisfeita. E a vida de todos os dias Ihe parecia insuportável. Não tenho muita certeza, mas acho que tentou o suicídio alguma vez... sem muita conviçção. O espantoso em minha mãe era que, depois de dois dias de crise... ela se levantava da cama como se nada tivesse acontecido... e era outra vez a mulher forte e voluntariosa...e de bom humor de sempre" (SAURA, 1977).
} 
em que apareça jovem e sorridente - vivendo de modo radical a experiência de encontrar-se diante do que foi outrora.

Os recursos que tipificam a linguagem cinematográfica permitem a Saura captar a imaginação dos personagens, construindo uma narrativa em que o que importa é representar os conflitos psicológicos dos seus personagens - seus medos, angústias, sonhos e lembranças. As fronteiras entre sonho e realidade frequentemente se dissipam e representam desta forma o imaginário fragmentado de seus personagens, que devaneiam, dormindo ou acordados. Avellar (1981) lança outra possibilidade para a troca de vozes: se pensarmos numa visão mais realista, a explicação satisfatória seria que Luis escreve um livro autobiográfico e toma a crise do casamento da filha como um dos temas, e Elisa lê parte desse relato. Não descartamos essa possibilidade, mas preferimos as apontadas anteriormente porque estariam mais próximas à maneira de escrever de Saura, que, por vezes, se utiliza dos matizes do surrealismo, o que inclui os sonhos, imaginações e mundo interior dos personagens.

Em seguida, no pensamento de Elisa, na casa de Madri, Luis se arruma para ir embora, sem explicação, abandonando a esposa e as filhas. E, novamente, com voz masculina, Elisa conta sobre a fuga do pai: diz que quando tinha nove anos, o pai havia saído de casa para sempre, e que nada havia falado nada para ninguém. Antes de ir embora, porém, havia ido ao quarto das filhas para se despedir: Isabel estava dormindo, mas ela estava acordada. Disse que ia dar um passeio; mas nada levou, não deixando nenhum bilhete ou nenhuma pista de onde podia estar. Simplesmente sumiu silenciosamente.

A sequência mostra Ana reconhecendo um corpo para saber se era de Luis. A narração continua com voz de homem (Luis), falando de Elisa. Ela lembra das fotos do pai rasgadas na lixeira e se dá conta que de alguma forma o seu pai havia morrido. Lembra que ficou triste e que a irmã chorou desconsoladamente. Em suas lembranças, cita que separação e divórcio ${ }^{5}$ eram coisas que se ouviam na escola, mas que não aconteciam. A mãe começou a trabalhar e chegava tarde a casa. No fundo, revela Elisa que, embora a mãe não admitisse, preferia ter encontrado Luis morto para se sentir livre e fazer o que tinha

\footnotetext{
${ }^{5}$ A legalização do divórcio deu-se na Espanha no ano de 1981. O filme foi escrito em 1977, por isso era ainda um assunto tabu.
} 
vontade, para começar uma nova vida que desejava, mas que não conseguia enquanto ele estava vivo. $^{6}$

Na sequência da narrativa do filme, Elisa vai à cidade telefonar para Antonio (seu marido) para avisar que ficará na casa do pai por dez dias. Ele insiste em acompanhá-la, mas ela diz que prefere ficar sozinha. Ao voltar para casa, ela e o pai preparam o almoço e conversam sobre a solitária vida de Luis e sobre o que ele escreve no diário. Luis revela que escreve sobre si próprio, como se fosse uma autobiografia. Elisa pede para ver os textos; em princípio, Luis concorda, mas depois desiste, dizendo que precisa revisá-los antes de mostrá-los.

Na cena seguinte, Luis e Elisa chegam de carro à escola onde ele ensina literatura para meninas, grande parte delas órfãs. Enquanto descem as escadarias da escola, Elisa pergunta ao pai porque ela havia estudado em escola de freiras; ele responde que havia sido ideia da mãe. Encontram Soror Trinidad e Luis lhe apresenta a filha. Enquanto caminham até a sala de aula, várias meninas passam correndo pelos corredores e Elisa comenta com Soror Trinidad que quando ela estudava em colégio de freiras, todas as crianças andavam em fila e que não podiam sair da linha. Soror Trinidad responde que as coisas haviam mudado. Elisa complementa que à noite tinham que dormir com os braços cruzados para evitar as tentações. Em seguida, Luis e a filha entram na sala de aula. Ele apresenta Elisa às meninas e diz que ela vai ajudá-lo a ensaiar a peça El gran teatro del mundo, de Pedro Calderón de la Barca: uma das alunas representará o Autor Soberano e Elisa representará O mundo.

Terminado o ensaio, a próxima cena mostra Elisa, já em casa, lendo os textos do pai, sem que ele soubesse. Logo em seguida, Saura mescla uma cena em que Elisa e o pai leem um livro juntos: Elisa lê uma parte, em inglês, e Luis segue lendo em espanhol. $\mathrm{Na}$ sequência, Luis anda pelo escritório, muito pensativo, e em seguida aparece novamente a cena em que Elisa lê os textos do pai. Trata-se do mesmo texto do início do filme, só que

\footnotetext{
${ }^{6}$ Especulamos que Ana, protótipo da mulher burguesa, tivesse medo de perder a condição de mulher casada com um homem de prestígio na sociedade, por isso ela refutava a possibilidade de separação. A morte do marido, nesse caso, resolveria o problema de Ana.
} 
agora lido por Elisa, com sua própria voz. Na verdade, Elisa está lendo um texto sobre ela, mas escrito pelo pai.7

Considerando que este texto é o mesmo lido na abertura do filme com a voz de Luis, podemos sugerir, novamente, o uso da metaficção - ou seja, o texto é escrito pelo autor (Luis) e interpretado por Elisa - como personagem. Na sequência, Elisa ouve a buzina do carro do pai e rapidamente guarda os textos que lia e o espera sentada na mesa, onde terminava um trabalho de colagem de fotos de revista em uma cartolina. Luis entrega uma carta de Antonio (marido) para ela, na qual ele diz estar preocupado porque ela parecia distante e perguntava por que ela não Ihe contava o que estava acontecendo. Depois de ler, Elisa amassa a carta e volta a trabalhar nas colagens.

Luis se senta com a filha e os dois conversam sobre a vida conjugal de Elisa, que revela perceber o quanto Antonio se afastou da sua vida. Ela diz achar estranho viver tantos anos com uma pessoa e ao final perceber que não a conhece realmente; ainda assim, não tem coragem de se separar. Luis comenta que essas situações sempre nos destroem e, que vistas de fora, as coisas não são assim, tão dramáticas. Aconselha que Elisa pense duas vezes antes de tomar uma decisão. Depois de aconselhá-la, comenta que o passado, às vezes, tem mais força do que pensamos, por mais que tentemos destruí-lo. Esse comentário sobre a força do passado pode ser uma referência sobre o próprio passado do protagonista que fugiu de casa para viver sozinho em busca de sua identidade individual, aparentemente para escapar da convivência familiar, e que, já na velhice, solitário e doente, parece carregar a culpa pela dor que causou à mulher e às filhas quando as abandonou. Também há grande possibilidade de ser uma referência ao passado associado à Guerra Civil espanhola, que marcou terrivelmente a população e deixou marcas presentes na atualidade.

Na continuação da cena, Elisa revela que havia se enganado com Antonio e que eles não se entendiam bem, e que ela não suportava a "necessidade idiota" de ele impor a sua vontade, sempre, como se Antonio tivesse que se afirmar o tempo todo. Comenta que sempre soube que não ficariam juntos e que mentia para si própria, porque sempre tinha medo de enfrentar algumas coisas, mas que era hora de mudar e começar uma nova vida.

\footnotetext{
${ }^{7}$ Trecho da fala do filme: "Conforme ia me afastando de Antonio... percebia que não podia voltar mais... para o homem que havia passado sete anos da minha vida. Eu fui embora... e agora sei que não vou voltar mais" (SAURA, 1977).
} 
Ainda na mesma cena, Elisa comenta que Antonio não era fiel e conta para o pai que o marido a traía com Sofia, sua melhor amiga. Diz que descobriu através de um telefonema anônimo, no qual, em princípio, não acreditou, mas que entendia a atração de Antonio por Sofia: ela era muito bonita. Comenta que levou um tempo para reagir. 8

Elisa toma coragem e vai à casa de Sofia para falar com ela e a encontra morta. $\mathrm{Na}$ próxima cena, Antonio chega à casa de Luis para encontrar Elisa. Os dois saem no carro de Antonio para conversar. Luis comenta para si próprio que é possível "vivermos muitos anos com uma pessoa e no final nos darmos conta de que não a conhecemos". Elisa já havia feito esse comentário; agora Luis o repete e complementa que a vida nos desgasta e nos envelhece. Não sabemos neste ponto se a história sobre Sofia é fruto da imaginação de Elisa; ela se encaixaria na narrativa, entretanto, para compreendermos a evolução do percurso psicológico de Elisa - partindo da crise do casamento e da suposta traição até o estado atual, em que se encontra vivendo com o pai e disposta a começar uma nova vida. Ainda na cena anterior, quando Luis comenta para si próprio um texto já falado por Elisa e há novamente troca de vozes, mantemos as três possibilidades que mencionamos anteriormente: dois personagens fundidos em apenas um; uso da metaficção e a versão de que Elisa lê o livro do pai, que escreve sobre ela.

Na sequência, dentro do carro indo em direção à casa de Luis, Elisa e Antonio têm uma conversa difícil, que finaliza o relacionamento do casal. Depois de romper com Antonio, Elisa sai caminhando pelo campo até a casa do pai. A cena no espaço fechado, dentro do carro, de acordo com García Ochoa (2008), representa o bloqueio sentimental de Elisa. Por outro lado, sair do carro e caminhar pelo campo confirma sua intenção de se desprender de todas as ataduras que a unem ao mundo exterior para seguir os passos do pai.

Na cena seguinte, Elisa tira uma máscara do rosto, parecendo, em princípio, que está tirando a própria pele. Depois, veste-se como se fosse para uma festa, se maquila, toma uma dose de bebida, vai até o escritório do pai, desliga a música que ele está ouvindo e

\footnotetext{
${ }^{8}$ Trecho da fala do filme: "Me joguei na cama e fiquei lá... em silêncio. Meu mundo caiu. Em um instante entendi o fracasso... de uma relação que nunca havia dado certo. Não sabia o que fazer. Sofia, minha amiga. Comecei a pensar que era uma brincadeira, ou mentira. Saí de casa e andei pela rua, em choque. Não sabia o que fazer. Acho que nessas horas... ficamos mais conscientes de nosso desespero. Fui a uma loja... e comprei uma bobagem, uma coisa inútil que... logo joguei no lixo. Só sabia que não podia voltar para casa sem saber o que faria. E se fosse mentira? Há pessoas capazes de fazer essas coisas. Me sentia sozinha, muito sozinha..." (SAURA, 1977).
} 
caminha até a pedra onde aconteceu o "crime da viúva". Joga a bebida em cima das flores de plástico que estão ao lado da pedra e recita o poema de Garcilaso de la Vega: "¿Quién me dijera, Elisa, vida mía, cuando en aqueste valle al freco viento andábamos cogiendo flores, que había de ver, con largo apartamiento, venir el triste y solitario dia que diese amargo fin a mis amores?" (SAURA, 1977).9 A seguir, Elisa imagina uma sombra se aproximando por trás, se vira e vê Antonio, que a atinge com vários golpes de faca, matando-a. Seguindo-se a essa cena em que Elisa se imagina no lugar da viúva assassinada, começa uma cena que mostra o sonho de Luis com carcaças de animais. Na próxima cena, Luis está caminhando sozinho pelo campo e refletindo sobre a liberdade que sentia depois de ter passado a noite em claro escrevendo e pensa que gostaria de prolongar aqueles momentos de plenitude, quando se sentia realmente vivo. Entendemos que Luis escreve como forma de exorcizar os pensamentos negativos sobre dor e morte, como uma catarse para sublimar a angústia e sofrimento. De repente, Luis sente uma dor, a dor que não sentia há algum tempo. Vemos então seu médico saindo depois de atendê-lo em sua casa, quando Luis fica sabendo que precisa ir para o hospital fazer alguns exames. Na sequência, Elisa vai dar aula no lugar do pai. Na escola, as alunas encenam, com Elisa agora, a peça El gran teatro del mundo.

Ao voltar para casa, Elisa não encontra o pai na cama, onde o deixou. Preocupada, sai para procurá-lo e o encontra morto, perto da pedra onde a viúva havia sido assassinada. A cena final mostra Elisa no escritório de Luis, escrevendo as memórias, que agora são narradas com a voz da própria Elisa. ${ }^{10}$

O filme termina com a mesma cena com a qual começa: o carro da família de Luis aproximando-se de sua casa. O texto da narração é o mesmo do começo do filme, só que

\footnotetext{
${ }^{9} \mathrm{O}$ fragmento da fala do filme acima pertence à Égloga Primera Garcilaso de la Vega, cuja estrofe complete, posta em boca do pastor Nemoroso diz: "¿Quién me dijera, Elisa, vida mía, / cuando en aqueste valle al fresco viento / andábamos cogiendo tiernas flores, / que había de ver con largo apartamiento / venir el triste y solitário día / que diese amargo fin a mis amores? / El cielo a mis dolores / cargo la mano tanto / que a sempiterno llanto / y a triste soledad me ha condenado; / y lo que siento más es verme atado / a la pesada vida y enojosa, / solo, desamparado, / ciego sin lumbre en cárcel tenebrosa" (GARCILASO DE LA VEGA, 2003, p. 45).

${ }^{10}$ Trecho da fala do filme: "Fazia anos que não via meu pai. Na verdade não senti muito a sua falta. Quase nunca escrevia para ele. Apenas alguns cartões postais para dizer que estava bem. E que Antonio e eu mandávamos um beijo carinhoso. Me entristecia a idéia de vê-lo doente... recuperando-se de uma recente cirurgia. A doença do meu pai coincidiu com a crise no meu casamento. Bem, com uma das crises. Quando recebi o telegrama de minha irmã Isabel... me avisando sobre a doença do papai... e depois do telefonema angustiado da minha família... foi que me dei conta da gravidade da situação... e da necessidade da minha presença em Madri. Olhe o egoísmo humano. Finalmente encontrei... uma desculpa para ficar fora de casa alguns dias... e refletir calmamente sobre minha situação. Conforme ia me afastando de Antonio... percebia que não podia voltar... para o homem com quem havia passado sete anos da minha vida. Eu fui embora, e agora sei, para não voltar mais" (SAURA, 1977).
} 
agora a narração é sobre Elisa e feita por Elisa, diferente do começo do filme, que era sobre Elisa, feita por Luis. Assim como Elisa assumiu o lugar do pai na casa e no trabalho, também assumiu o livro autobiográfico que ele escrevia, retomando a sua própria história, agora contada sob a sua ótica - daí a mudança de foco no final do filme. Como observamos, o texto é, entretanto, exatamente o mesmo do início; Elisa retoma a obra de Luis, no mesmo ponto e da mesma forma, convertendo o texto em um argumento espiral. Finalizamos, retomando a ideia de que no filme o que importa não é a trama e sim como transformar em imagens as reflexões, sonhos e imaginações dos protagonistas, o que Saura faz, algumas vezes utilizando-se de elementos do surrealismo.

\subsection{O romance}

Se no filme Elisa, vida mía Saura narra os sonhos, a imaginação e os conflitos existenciais dos protagonistas com a mediação das imagens, no romance, com o mesmo título, ele se aprofunda no mundo interior dos protagonistas, detalhando o perfil psicológico dos personagens. Seguimos com a síntese do romance (2004), com o objetivo de evidenciarmos as semelhanças e diferenças em relação ao filme escrito em 1977.

O romance começa da mesma maneira com que o filme terminou: Elisa sentada na cadeira do pai no escritório, escrevendo com voz masculina sobre a vida de Luis: "Estaba cansado, se quitó las gafas y cerró los ojos" (SAURA, 2004, p. 5). A narrativa segue com a descrição do dia da morte de Carmen, ocorrida perto da casa de Luis: "[...] observaba cómo la moto aparecía en la lejanía apretándose contra la tierra y aproximándose cada vez más [...]" (SAURA, 2004, p. 5). Diferentemente do filme, nesta passagem do romance, Saura descreve minuciosamente o dia do crime e a descoberta de que a mulher assassinada era Carmen. Neste ponto ainda não sabemos que ela havia sido namorada de Luis, mas o autor já revela a melancolia do personagem ao lembrar-se desse dia: "[...] Recordó que no fue de día, sino de noche cuando aquello sucedió, y que nunca hubiera imaginado que esa noche iba a ser un camino sin retorno que conduciría Carmen a la muerte [...]" (SAURA, 2004, p. 6).

A narrativa segue com a descrição da paisagem e da estrada de terra que levava a Melque, povoado em que ficava a casa de Luis (a estrada que aparece no começo do filme). Em seguida, Saura descreve o carro da família, que já não é mais o mesmo carro que aparece no filme. É um carro que mostra sinais da modernidade, com cadeiras de couro e 
câmbio automático. Aqui Saura delineia a Espanha moderna, do século XXI, já que o romance é de 2004. Na próxima passagem, o autor traça as características físicas e psicológicas das filhas de Luis (ausentes no filme) e nos faz retomar a ideia de dois personagens se fundindo em um, quando Luis comenta: "Elisa era su preferida, y no porque fuera la mayor, que eso era circunstancial, sino porque había algo en ella en lo que se reflejaba y reconocía. Y había algo en él que era de ella [...]" (SAURA, 2004, p. 9, grifos nossos).

A próxima passagem mostra o aniversário de Luis, quando a família vai visitá-lo. Assim como no filme, a família chega à casa de Luis e ele não se encontra. No romance, porém, Saura descreve os pensamentos de Luis, que lembra que tinha que sair para comprar pão e vinho para receber a família. Na sequência, as duas irmãs (dentro do carro) observam a paisagem e conversam sobre o lugar. Isabel comenta que não viveria naquele lugar, enquanto Elisa, apesar não considerá-lo o mais acolhedor do mundo, achava-o atrativo. Ainda dentro do carro, Elisa pensa no pai e se pergunta sobre quais teriam sido as razões da sua fuga. Em seguida, ela se recorda da cirurgia do pai, quando o reencontrou depois de passados vinte anos de sua fuga; e se entristece por saber que irá encontrá-lo ainda sofrendo as sequelas da doença. E nesse momento imagina, assim como no filme, que a doença do seu pai coincidiu com uma das crises do seu casamento: "La enfermedad de su padre coincidió con la crisis de su matrimonio. Bueno con una de las crisis, porque Antonio y ella se llevaban mal, y estaba claro que así no podían continuar. El dolor de una separación definitiva le rompía el corazón y apenas le dejaba vivir [...] (SAURA, 2004, p. 14). Ainda nessa parte, Elisa se recorda do telegrama da irmã anunciando a recaída do pai e decide ir à Espanha para vê-lo e, nesse momento, ela reflete sobre o egoísmo humano: "[...] Y lo que es el egoísmo humano: encontró al fin un pretexto para alejarse de casa unos días, para recapacitar tranquilamente sobre su situación y para tratar de poner orden en sus sentimientos [...]" (SAURA, 2004, p. 14). Confirma-se a ideia da menor relevância da trama - no filme e no romance -, e a prioridade do aspecto psicológico dos protagonistas, já que nessa e na maior parte das passagens nos deparamos com as reflexões dos personagens - aqui, de Elisa sobre o egoísmo do ser humano e sobre seus sentimentos e sofrimento.

A família chega à casa de Luis, celebra seu aniversário e Elisa resolve ficar uns dias com o pai - livro e filme compartilham esta mesma passagem/cena. Entretanto, no livro, as descrições psicológicas dos personagens, da casa e da paisagem são muito mais Eutomia, Recife, 24(1): 32-59, Set. 2019 
minuciosas: "El coche cruzó el precario puente de tablones de madera que atravesaba el riachuelo, y dejando la arboleda se dirigió a un conjunto de construcciones de una sola planta cercada de piedra y mampostería [...]" (SAURA, 2004, p. 17). A descrição do interior da casa no livro (como também na representação pictórica do filme) sugere uma ideia de tristeza, abandono e melancolia: "[...] el color rojo avinagrado, almagre lo llamaban en Andalucía, un color que oscurecía las paredes, resaltando por contraste la luz que provenía de la ventana sin vidrillos ni cortinas [...]" (SAURA, 2004, p. 19).

Depois dessa passagem, destacamos um diálogo entre as duas irmãs, em que Isabel comenta que o pai havia rejeitado o telefone celular presenteado por ela no Natal:

Ni siquiera tiene teléfono. Le regalamos para navidades un móvil, ¿Y sabes lo que dijo? ¿Y para qué quiero yo ese chisme? ¿Y qué haces si te pones enfermo, sin teléfono y sin nadie en los alrededores?, le pregunté. ¿Sabes qué me contestó? - Elisa se armó de paciencia, nunca le habían gustado los acertijos, así es que le dijo que no, que no lo sabía -. Me contestó que era preferible morir solo que mal acompañado (SAURA, 2004, p. 21).

Essa rejeição mostrada pelo personagem corrobora com nossa suposição sobre o trauma de Saura em relação aos telefones, porque durante a Guerra Civil levavam as más notícias e anunciavam a morte de pessoas conhecidas.

Na sequência da trama, vemos que, assim como Luis reflete sobre a inutilidade de sua vida no filme e como escrever Ihe serve de terapia, Elisa o faz no romance: havia trabalhado em várias coisas, algumas vezes ajudando o marido, viajando de lá para cá, acompanhando turistas em Paris, mas considerava que essas atividades só tinham servido para ganhar dinheiro e passar o tempo. Sentia-se inútil e vazia. A única coisa que a deixava bem consigo mesma era escrever, porque servia para se conhecer melhor. Essa reflexão de Elisa é logo depois contraposta pela de Luis, que valoriza a profissão que escolheu, a de professor: "[...] tenía que reconocer que él había tenido la suerte de dedicar una parte de su vida a la enseñanza, un trabajo que le gustaba y satisfacía" (SAURA, 2004, p. 23). Personagens com ofício de escritor, professor ou ligados à arte ou similares já haviam aparecido em outros filmes de Saura: um jornalista no romance Esa luz (1998); um bibliotecário em El sur (1992); atores em Ay, Carmela (1990); um poeta em La noche oscura (1989); um professor universitário em Los zancos (1984), assim como em Elisa, vida 
mía (1977) ${ }^{11}$; uma escritora em Antonieta (1982); um autor-ator-espectador em Dulces horas (1981); um diretor de teatro em Los ojos vendados (1978); um editor em La prima Angélica (1974) e os jogos teatrais da trilogia flamenca e em outras obras (SÁNCHEZ VIDAL, 1988; RUIZ VEGA, 1999). ${ }^{12}$

Na sequência do romance, destacamos o momento em que Elisa entra no escritório do pai e lê o seu diário (autobiografia). No filme, a leitura do texto se refere a um homem, que se queixa do cansaço de alguém que não havia chegado a lugar algum, que não podia dizer que se havia enganado. No romance, Elisa lê um texto semelhante ao lido no filme, só que se refere a uma mulher: "[...] No podía decir que vivía engañada, porque ella misma había participado en el engaño [...]" (SAURA, 2004, p. 34). No romance, Elisa fica intrigada com o texto que acaba de ler porque se refere a uma mulher e ela pensa que essa mulher podia ser ela.

Em seguida, Saura descreve as reflexões de Luis durante a comemoração do seu aniversário. A família o havia avisado que iria vê-lo para comemorar o aniversário. Ele havia tentado fazer que desistissem, mas não conseguiu: "[...] Le horrorizaban los cumpleaños, las navidades, las bodas y los entierros, y trataba de evitarlos. Pero esta vez no podía decir que no. Al fin y al cabo era su familia [...]" (SAURA, 2004, p. 39). Essas reflexões oferecem duas interpretações: a primeira é que sublinham o caráter melancólico de Luis, ou seja, a opção pela vida solitária em repúdio à vida social; a outra reafirmaria a hipótese de uma narrativa centrada no aspecto psicológico dos personagens, com a trama funcionando mais como pano de fundo para mostrar seu percurso existencial - suas relações, seu conflitos psicológicos, pensamentos, devaneios e sofrimento.

A sequência, como já mencionamos, segue o roteiro do filme. Assim, continuamos nossa análise a partir do momento da partida da família e da permanência de Elisa com o pai. Com a partida da família, Elisa e Luis saem pelo campo para um passeio. Interessa-nos aqui mostrar as descrições da paisagem e como ela se articula com o aspecto psicológico dos protagonistas, além da descrição da descoberta do crime de Carmen. Lembramos que o filme trata mais vagamente do "crime da viúva", enquanto no romance Saura explicita que

\footnotetext{
${ }^{11}$ Lembramos que Saura não deixa explícito, no filme (1977), que Luis era um professor universitário em Madri antes de se mudar para Melque e começar a dar aula de literatura em um colégio religioso. Essa parte do passado de Luis somente é explicitada por Saura no romance.

${ }^{12}$ Essa profusão de personagens de profissões ligadas à arte e cultura lembra o caráter multifacético de Carlos Saura.
}

Eutomia, Recife, 24(1): 32-59, Set. 2019 
se trata da morte da ex-namorada de Luis, e que, por vezes, a lembrança da cena desencadeia a melancolia do protagonista.

Na descrição das paisagens, verificamos que Saura valoriza o campo, que associa campo-cidade-melancolia e confere ao campo características positivas: "[...] Elisa respiraba con delectación el aire fresco del campo, y mientras caminaba al lado de su padre contemplaba el ancho paisaje que se extendía frente a ella [...]" (SAURA, 2004, p. 65). Na descrição da descoberta do crime de Carmen, Luis comenta que uma manhã estava fazendo uma caminhada e viu um vulto no caminho e, quando se aproximou, percebeu que era uma mulher e que ela estava morta - assassinada a facadas. Destacamos dessa passagem duas referências. A primeira é sobre a reação de Luis, que é diferente do filme, pois no romance ele reconhece a mulher como Carmen, uma professora da escola em que ele trabalhava, e mais tarde sabemos que era sua ex-namorada:

Me quedé paralizado, porque pensé que el asesino estaba rondando por ahí y podría matarme a mí también. Luego, más tranquilo, al ver que estaba yo solo en el camino, me fijé en ella. Me dio un vuelco el corazón cuando caí en la cuenta que de que la conocía: se llamaba Carmen Alvarado y era maestra en la escuela en donde daba clases [...] (SAURA, 2004, p. 67).

A segunda é a reação de Elisa - o que ela pensa enquanto o pai conta a história de Carmen: "¡No podia ser! ¡Había visto esa imagen brutal antes! Antonio abalanzándose sobre ella con un cuchillo en la mano" (SAURA, 2004, p. 67). Retomamos nossa hipótese de metaficção, aqui de uma forma diferente, pois Saura parece se comunicar com Carmen, romance de Prosper Mérimée (1845) adaptado para uma ópera por Bizet (1875). Este livro narra o amor de Don José por Carmen, uma mulher inconstante, que é morta pelo amante. Elisa se vê no lugar de Carmen no momento em que Luis conta a história e, um pouco mais adiante no romance, quando conta para o pai que o marido a traía com Marta, sua melhor amiga, que ela considera como uma Carmen moderna.

Na sequência, há uma passagem não compartilhada pelo filme. Elisa e o pai conversam e ela pergunta se ninguém o havia perturbado durante a noite na casa, que tinha ares de abandonada. Ele comenta que uma única vez, em uma noite de inverno, em que ventava muito e fazia um frio intenso, um homem batera na janela. Era um homem que havia se perdido e pedia abrigo. Luis o acolheu, emprestou-lhe roupas porque as roupas dele estavam molhadas, voltou a dormir e sonhou com o homem. A descrição do sonho nos interessa porque apresenta traços de surrealismo, e Saura, apesar de possuir uma maneira 
muito própria de narrar seus filmes e romances, deixa transparecer, às vezes, a influência de Buñuel em algumas cenas/passagens de Elisa, vida mía (filme e romance):

Recuerdo que soñé que ese hombre se alejaba de espaldas perdido en medio de una ventisca, apenas avanzaba, porque el viento se lo impedía. Se detuvo agotado para tomar fuerzas y entonces vi que ese hombre perdido en la inmensidad de la nieve y a punto de morir helado era yo. Me desperté, y efectivamente, estaba aterrado de frío, porque las mantas se habían caído al suelo (SAURA, 2004, p. 73).

Na passagem seguinte, Elisa se pergunta o que está fazendo ali, em um quarto sem a mínima comodidade - longe de tudo, sob uma luz amarelada e fraca, que impossibilitava a leitura na cama, costume a que Elisa se havia habituado para conciliar o sono. Sentiu-se desolada por não ter calculado melhor os inconvenientes de sua estada num lugar tão afastado de tudo e de todos. Já mencionamos anteriormente que a visão de Elisa sobre viver no campo se alterna: sua pessoa urbana, que vive em Paris, se assusta com a precariedade da vida campestre; entretanto, a vida rural a conforta também, afastando-a dos problemas da cidade e da vida conjugal, e gradualmente ela vai se reconciliando com o campo.

O segundo capítulo se inicia com um sonho de Luis em que aparecem cavalos esquartejados. Depois desse sonho, Saura narra a fuga de Luis, o sofrimento de Ana (sua esposa) e de suas filhas. Em seguida, a relação entre a melancolia de Elisa e as músicas de Rameau e Erik Satie e a associação dessas músicas com a volta de Elisa à infância. O segundo capítulo é particularmente fiel ao filme. O que acrescentamos na nossa análise é a descrição de Ana, esposa de Luis, ausente no filme. Era uma mulher que representava o protótipo de mulher burguesa: se vestia muito bem, usava jóias discretas e cuidava muito bem do cabelo e da pele. No romance também há um comentário sobre Ana inexistente no filme. Depois de superada a separação, Ana tornou-se administradora do negócio familiar e se casou novamente.

Uma outra passagem do romance, inexistente no filme, é a reflexão de Luis sobre como gostaria de escrever: "[...] hubiera gustado escribir como si fuera una salmodía, una interminable fuga de Bach, o como los monjes y santones que repetían una y otra vez las mismas frases, yendo y viniendo, retomando lo dicho retorciéndole hasta el infinito [...]" (SAURA, 2004, p. 92). Complementa que gostaria de escrever deixando-se levar pela imaginação, por algumas imagens e por algumas recordações, mas sempre se entregando a 
esse fluir de palavras e de frases que às vezes surgiam na cabeça como uma explosão. Gostaria de escrever sem se arrepender das repetições e reiterações. Ao contrário, pensava que essas repetições correspondiam aos estranhos mecanismos do seu pensamento, em que as imagens e textos apareciam e desapareciam como se fossem salmos. Essa passagem corrobora nossa análise, que identifica elementos do surrealismo na obra de Saura, pois se refere à escrita associada aos mecanismos do pensamento, uma das características do surrealismo.

O romance segue com a descrição da viagem de Luis, de Madri a Melque, com registros de seus pensamentos, que inicialmente refletem sobre a agonia de viver na cidade de Madri. Depois segue com Luis refletindo sobre religião e sobre a Bíblia. Na sequência, Luis se lembra da curiosidade das meninas do colégio religioso no primeiro dia de aula: "[...] las niñas le miraban con ojos curiosos, como diciendo: a ver qué nos va a enseñar este tipo que viene de la capital [...]" (SAURA, 2004, p. 102). Depois dessa passagem, a narrativa continua com o telefonema de Elisa para Antonio (seu marido) - no romance, o telefonema é dado pelo celular: "[...] Elisa caminaba por el recinto de la finca con el móvil pegado a la oreja [...]" (SAURA, 2004, p. 103). Enquanto falava com Antonio, admirava o campo, e ao desligar o telefone estava decidida a terminar a relação: "[...] lba a emprender una nueva vida sin Antonio, empezando de cero [...]" (SAURA, 2004, p. 104).

Depois dessa passagem, temos o almoço de Elisa e Luis, quando conversam sobre 0 assassinato de Carmen e Luis confessa que ela havia sido sua namorada. Também dialogam sobre o livro que Luis escreve, assim como na cena do filme. A seguir, pai e filha vão ao colégio onde Luis dá aula e Elisa participa do ensaio da peça El gran teatro del mundo, de Calderón de la Barca. Em uma passagem posterior, depois de alguns diálogos entre Luis e Elisa, em que eles discutem sobre literatura, cinema e artes, Luis começa a contar um sonho para Elisa, em forma de literatura: "[...] Iba caminando por el borde del abismo, un filo de obsidiana cuyas laderas se desplomaban perdiéndose en la brumas que ocultaban la deseada llanura [...]" (SAURA, 2004, p. 137).

Na próxima passagem do romance - cena inexistente no filme -, Luis conta um sonho para Elisa em que encontra um colega da escola pós-guerra onde havia estudado, que remete Luis às lembranças da guerra civil. Em seguida, em uma longa conversa com o pai, Elisa conta para ele que Antonio a traía com sua melhor amiga. No terceiro capítulo, Elisa e Antonio se encontram, e, assim como no filme, eles saem de carro e rompem a 
relação. Depois, também como no filme, Elisa tem um ataque histérico, para, em seguida, arrumar-se, maquilar-se e sair em direção à pedra, perto de onde acontecera o crime. Lá, recita o poema de Garcilaso de la Vega que deu origem ao seu nome e que também deu origem ao nome do filme e romance, e que faz menção ao final de seu relacionamento: "¿Quién me dijera, Elisa, vida mía..." (SAURA, 2004, p. 196).

A sequência é bastante fiel ao filme. Elisa, perto da pedra, novamente se imagina assassinada por Antonio. Na passagem seguinte, Luis se sente mal e começa a refletir sobre a vida e sobre seus próprios pensamentos. Sentia-se preocupado pelo fato de seus pensamentos serem os mesmos de sua adolescência, quando se perguntava o porquê da vida e por que ele estava ali. Conclui que o tempo havia passado, mas os pensamentos eram cíclicos; havia voltado ao romantismo da juventude, dando círculos ao redor dos mesmos pensamentos. Via-se refletido na filha, com a diferença da idade e da experiência, e pensava que já havia passado por problemas pelos quais ela ainda passaria. Mais uma vez vemos a possibilidade de fusão de dois personagens em um pela reflexão de Luis, acima comentada.

No final do IV capítulo, o romance segue com as lembranças de Elisa sobre a internação de Luis para ser submetido a uma cirurgia. Em seguida, já no V capítulo, Luis sonha com morte de animais novamente. Na sequência, sente-se mal e Elisa vai para o colégio no lugar dele para a representação da peça El gran teatro del mundo com as alunas. Quando volta, encontra o pai morto, perto da pedra onde acontecera a morte de Carmen.

O filme termina com a morte de Luis, mas a última parte do romance, intitulada $\mathbf{A}$ modo de epílogo, mostra as reflexões de Elisa, que decide viver na mesma casa onde seu pai havia vivido e contar a história de outra maneira - a sua maneira. Além de morar na mesma casa e gostar de viver isolada como o pai, Elisa também gostava de dar aulas para as alunas do colégio religioso, cargo que também herdou do seu pai. Estava disposta a contar a sua história e a do seu pai, mas que não era rigorosamente certa, porque havia muito de inventado e de imaginado. Mais uma vez entendemos que fica sugerida a hipótese da importância da representação do mundo interior dos personagens, pela confirmação acima de que imaginado e vivido frequentemente se fundem.

A intenção era que a história nunca terminasse, entre outras coisas porque ela não se propunha a terminá-la: sua ideia era deixar um final aberto. Como o pai, Elisa tinha vontade de produzir textos repetitivos, como uma salmodia ou como uma interminável fuga de Bach 
com suas variações. Também gostaria de compor música, pintar um quadro, escrever um romance, mas conhecia suas limitações. Sentia-se mais segura escrevendo à sua maneira, sem se pretender a nada importante, e com a liberdade de não ter que dar explicações a ninguém nem cumprir outra obrigação que não fosse a de passar o tempo recriando uma parte de sua vida. Assim, sentada na mesa que fora de seu pai, começou a escrever com voz masculina sobre a vida dele: "[...] Estaba cansado, se quitó las gafas de présbita, apoyó la cabeza entre sus manos y cerró los ojos [...]" (SAURA, 2004, p. 250).

\section{Breves notas sobre Polifonia e Intertextualidade}

Intertextualidade ou dialogismo é uma referência ou uma incorporação de um elemento discursivo por outro, podendo-se reconhecê-lo quando um autor constrói a sua obra com referência a textos, imagens ou a sons de outras obras e autores e até por si mesmo, como uma forma de reverência, de complemento e de elaboração do nexo e sentido deste texto/imagem. (BARROS; FIORIN, 1999).

Mikhail Bakhtin (2008) desenvolveu o conceito de polifonia em Problemas da poética de Dostoiévski. A partir do estudo de Dostoiévski, ele concebe a literatura como um tipo especial de linguagem que permite ver as coisas que estão obscurecidas em outros discursos, acreditando mesmo que o romance funciona como um órgão de percepção. É através do literário, que ele vai apreender o conceito de vozes e instituí-lo como princípio arquitetônico da prosa romanesca. Bakhtin afirma que os elementos históricos, sociais e linguísticos atuam de forma decisiva no cerne da personalidade do indivíduo e se manifestam de forma dialógica em seus discursos. Também afirma que todo discurso, por mais simples que seja, está inevitavelmente permeado de inúmeros discursos de natureza social, cultural e ideológica. A esta propriedade intrínseca dá se o nome de dialogismo, visto que sob este ponto de vista nenhum discurso pode ser erguido sob a forma de um verdadeiro monólogo, mas está perpassado de outras vozes e textos.

Julia Kristeva (1999) retoma Bakhtin, e afirma que, para se tornarem dialógicas, as palavras precisam encontrar outra esfera de existência: precisam tornar-se discurso. Assim, o dialogismo bakhtiniano designaria a escritura, ao mesmo tempo, como subjetividade e comunicatividade ou, melhor dizendo, como intertextualidade -, na definição de Kristeva. Dessa forma, o dialogismo bakhtiniano ou a intertextualidade de Kristeva podem ser definidos em termos de uma interação textual que se produz no interior de um só texto e 
que permite entender as diferentes sequências ou códigos de uma estrutura textual precisa como também de transformações de sequências ou de códigos tomados de outros textos. Para o leitor, que é sujeito cognoscente, a intertextualidade é uma noção que se tornará índice da maneira de como um texto lê a história e se insere nela. ${ }^{13}$

A partir dos termos dialogismo de Backtin e intertextualidade de Kristeva, Genette (1989) propõe um novo termo: transtextualidade, como tudo que coloca o texto em relação, manisfesta ou secreta com outros textos, redefinindo intertextualidade. Ele utiliza o termo de Kristeva como paradigma terminológico, mas o define de forma restritiva como uma relação de co-presença entre dois ou vários textos, isto é, essencialmente e o mais frequentemente como presença efetiva de um texto em outro. A partir dos conceitos apresentados sobre o desdobramento do dialogismo em intertextualidade, feito por Kristeva e do desdobramento do conceito de intertextualidade redefinido por Genette a partir do conceito de Kristeva, elaboraremos nossa análise sobre polifonia e intertextualidade em Elisa, vida mía (filme e romance).

Consideramos que o filme (1977) e o romance (2004) Elisa, vida mía foram escritos de maneira polifônica, ou seja, nestas obras, se entrelaçam a poesia, o teatro, a música e a fotografia. Ruiz Vega afirma que Saura desenvolveu seu trabalho em forma de quadrilátero: "[...] Uno de los lados de este ring creativo es la fotografía, otro el cine, el tercero la música y el cuarto la literatura (enunciados por orden de aparición)" (RUIZ VEGA, 1999, p. 80). Em Elisa, vida mía, filme (1977) e romance (2004), Saura conseguiu reunir em um só texto todas essas formas de expressão artística. Nesta parte do trabalho, buscaremos identificar como essas linguagens se articulam na produção de Saura e, mais especificamente, com a melancolia que a permeia.

Em relação à Égloga I, de Garcilaso de la Vega, o próprio Saura confessa ter lido essa poesia quando era estudante, em um livro didático sobre literatura espanhola. Anos depois, relendo Garcilaso de la Vega, se interessou pelo mistério e pela dor reflexiva de uma paixão não correspondida apresentados na Égloga I: "[...] Total, que ese fue el primer impulso para escribir el guión. Uno se sorprende al ver cómo por los caminos más inesperados: una imagen,

\footnotetext{
${ }^{13}$ Em relação aos conceitos de polifonia textual, heterofonia e heterologia na História da Literatura Espanhola e, dentro dela, no preciso momento do nascimento do romance moderno (Lazarilho de Tormes, Dom Quixote) convém tomar em conta o que foi dito por MIRANDA POZA (1999, p. 238-239).
}

Eutomia, Recife, 24(1): 32-59, Set. 2019 
un sueño, un recuerdo, un poema, un cuadro..., se puede organizar el andamiaje de una obra de teatro o de una película" (SAURA, 2004, p. 79).

Na citação anterior, Saura afirma que essa poesia foi fonte de inspiração para começar a escrever o roteiro do filme Elisa, vida mía (1977). Trata-se de uma poesia triste, sobre amor não correspondido, e seria uma fonte apropriada de inspiração para a atmosfera de melancolia de Elisa, vida mía (filme e romance). Os estudos sobre a melancolia amparam essa possibilidade, porque, entre outros fatores, ela também pode estar associada ao mal do amor, resultante de uma paixão não correspondida, ou da busca por um ideal amoroso impossível de atingir. Ambos levam ao desânimo, falta de apetite, tristeza, desconfiança, dúvida, etc.

No romance, quando ainda adolescente, Luis escreve uma poesia, também triste, impressionado por uma visita a um cemitério. Já adulto, se queixa por nunca ter escrito um poema como o de Garcilaso de la Vega: "Él hubiera dado cualquier cosa por haber escrito un poema de Garcilaso de la Vega que le conmovía, de una belleza difícil de describir, pero que englobaba ternura, sentimiento, pasión y también tristeza" (SAURA, 2004, p. 16).

Para finalizar, discutiremos o intertexto com o texto de Calderón de la Barca, El gran teatro del mundo (1643-1645). Luis havia feito uma adaptação infantil dessa peça de teatro e a ensaiou com as alunas da escola onde lecionava. Nessa obra, Deus é o Autor Soberano que mantém contato com o Mundo e determina tudo o que deverá ser realizado:

- Ya sé que si el hombre pudiera elegir, nadie querría hacer el papel de sentiry padecer. Todos querrían hacer el papel de mandar $Y$ dirigir, sin mirar, sin advertir que también eso es representar, aunque ellos piensen que es vivir. Pero yo, el Autor Soberano, sé bien qué papel hará cada cual mejor.

El Mundo cogió los papeles que había sobre la mesa.

- Y ahora yo, el Mundo, voy a repartir los papeles que el Autor Soberano ha designado para cada uno, y les daré sus atributos. - Revisó los papeles y seleccionó uno -. A ver..... Paquita! [...] (SAURA, 2004, p. 243).

O personagem Mundo tem duas portas como signo espacial, que funcionam como entrada e saída dos personagens e os signos verbais e não verbais: o berço, que metaforicamente se refere ao nascimento, e o sepulcro, que simboliza a morte: "[...] ya previno mi discurso / dos puertas: la una es la cuna / y la outra es el sepulcro" (NOGUEIRA, 2002, s.p.).

Na adaptação infantil de Luis, o Autor Soberano define os papéis e o Mundo distribui e apresenta as características de cada personagem. A aluna designada para representar o 
rei recitou: "[...] Yo seré el Rey. Podré mandar, gobernar un país, tener honores [...]" (SAURA, 2004, p. 243). O rei recebe púrpura e coroa, símbolos do poder e riqueza.

A escolhida para representar a formosura disse: "[...] -iQué maravilla! Yo seré la Hermosura humana. Se tontoneó por el escenario orgullosa y feminina [...]" (SAURA, 2004, p. 244). Formosura recebe a beleza e as cores das flores, símbolos da vaidade feminina.

A aluna que representou o Rico, o todo poderoso, pediu riqueza e felicidade e recebeu tesouros - símbolo da riqueza. A que recebeu a ordem de ser lavradora e trabalhar de sol a sol para ganhar o pão, recebeu uma enxada e protestou, dizendo que não queria e questionou o papel: "[...] -¿Por qué yo tengo que hacer el papel de Labrador en esta comedia? ¿Por qué no me dais el papel del Rey, o del Rico? ¿ Es que acaso son ellos mejores que yo, para que sea mejor su papel? [...]" (SAURA, 2004, p. 246). O Autor Soberano respondeu:

-Tú harás de labrador. A ti nada te he de dar, que haciendo de Labrador, sólo un azadón del Mundo recibes, y trabajas de sol a sol. Porque en esta representación cada cual tiene que hacer su papel. Y sólo es mejor aquel que haga BIEN su papel. Y no serán premiados unos más que otros, que tanto si es rico, pobre, labrador o la Hermosura, cobrarán el salario cuando ho hayan merecido. ¡En este Teatro del Mundo, toda la vida representación es! (SAURA, 2004, p. 246).

El gran teatro del mundo (1643-1645) é uma peça que trata de nascimento e morte, como já comentamos: "[...] Con música se abren a un tiempo dos globos: en el uno estará un trono de gloria, y en él el Autor sentado; en el otro ha de haber representación con dos puertas: en la una pintada una cuna y en la otra un ataúd" (NOGUEIRA, 2002, s.p.). Todos entram pela porta do berço, que simboliza o nascimento: "Salen la Hermosura y la Discreción por la puerta de la cuna" (NOGUEIRA, 2002, s.p.).

Uma voz representando a morte cobra de todos as boas ações, praticadas ou não: nesse momento, a porta que representa a morte, a do ataúde, é citada: "[...] Canta una voz triste dentro, a la parte que está la puerta del ataúd" (NOGUEIRA, 2002, s.p.). Na sequência, o Mundo faz o papel da morte, que vem tirar, de todos, o que receberam, acabando assim a comédia da vida. Como pode ser observado, o tema da obra gira em torno da morte, assim como outros textos que citamos neste capítulo, por isso destacamos como mais um texto melancólico que Saura tomou emprestado de Calderón para representar a melancolia dos personagens Elisa e Luis.

\section{Considerações finais}

Eutomia, Recife, 24(1): 32-59, Set. 2019 
Ao longo do nosso estudo, tivemos oportunidade de constatar que a importante obra do cineasta e escritor Carlos Saura está, por um lado, profundamente inserida numa preocupação da cultura moderna, que encontra a sua expressão já no século XVI. Por outro lado, essa obra representa uma resposta criativa, um modo de manifestar, por meio da arte, os conflitos históricos vividos pela Espanha nos séculos XX e XXI. Em Saura vive a memória da Guerra Civil, do pós-guerra, e como experiência pessoal, a ditadura, a transição e a democracia. Para integrar essas duas visões, decidimos averiguar a maneira como a memória histórica dos séculos XX e XXI estava presente na sua criação fílmica e literária.

A propósito da intertextualidade e a polifonia, contamos com as contribuições de Bakhtin sobre polifonia e de Kristeva e Genette sobre intertextualidade. Partindo do conceito de dialogismo ou polifonia, desenvolvido por Bakhtin a partir do seu estudo de Problemas da poética de Dostoiévski e dos desdobramentos do conceito de dialogismo bakhtiniano em intertextualidade, feito por Kristeva, e deste último redefinido por Genette, elaboramos nossa análise sobre polifonia e intertextualidade em Elisa, vida mía (filme e romance).

Sobre a relação intersemiótica de Saura (passagem da linguagem cinemática de Elisa, vida mía para a linguagem romanesca)-, verificamos que Elisa, vida mía (filme e romance) são textos de ficção, construídos através de flashbacks que resgatam o passado. Saura utiliza esta técnica para mostrar as lembranças dos personagens. Ao lançar mão de uma escrita intersemiótica, Saura adota técnicas representativas do cinema, da literatura, da pintura, da fotografia, do teatro, da pintura e música - tanto no filme, quanto no romance Elisa, vida mía, e através desse recurso Saura recupera a memória individual e coletiva, ao revelar uma memória oficialmente negada, que ele, através de sua arte multifacética leva aos cinemas e aos seus romances. Assim, as narrativas das duas obras compartilham a forma de flash-back - recurso mais tipicamente cinematográfico - que Saura também utiliza no romance, estabelecendo-se assim uma relação intersemiótica que possibilitou uma adaptação do filme para romance com alto grau de fidelidade.

Através do flash-back Saura, primeiramente no filme, em 1977, e posteriormente no romance (2004), apresentou as indagações, dúvidas, angústias e memórias do passado dos protagonistas. Também verificamos que Saura se vale da metaficção para revisitar a memória, tanto individual como coletiva/histórica. Este recurso funciona como instrumento 
de reconstrução do passado porque o cenário teatral funciona como metáfora visual dos seus arquivos, ou seja, um espaço imaginário depositário de recordações. Em Elisa, vida mía, a metaficção é marcada pela encenação do auto religioso El gran teatro del mundo pelas alunas do protagonista, que Saura utiliza como opção de um olhar auto-reflexivo sobre o passado.

Com a literatura, principalmente a do Século de Ouro Espanhol, Saura manteve diálogo com Garcilaso de la Vega, Gracián e Calderón, apresentando, principalmente no romance, trechos ou comentários sobre a obra desses autores suscitando, quase sempre, um traço de melancolia nas obras dos autores citados. Lembramos que o filme e romance retomam a história da Égloga I de Garcilaso de la Vega, uma poesia triste sobre amor não correspondido, que teria sido uma fonte apropriada de inspiração para a atmosfera melancólica de Elisa, vida mía (filme e romance).

Finalizamos, evidenciando o caráter multifacético de Carlos Saura, considerando que Elisa, vida mía, filme (1977) e romance (2004) foram escritos de maneira intersemiótica, ou seja, nessas obras se entrelaçam literatura, teatro, música e fotografia, e Saura se valeu dessas expressões artísticas que ele conseguiu reunir nos textos do filme e do romance para revisitar a memória individual dos protagonistas que suscita a memória coletiva / histórica, que consideramos, representa a memória coletiva / histórica da Espanha e da sociedade que sobreviveu aos horrores da Guerra Civil espanhola.

\section{Referências bibliográficas}

AVELLAR, J. C. Elisa na hora do lobo (1981). Disponível em: http://www.escrevercinema.com/Elisa vida mia.htm. Acesso em: 10 maio 2009.

BAKHTIN, M. Questões de literatura e estética: a teoria do romance. São Paulo: HUCITEC, 1988.

BAKHTIN, M.; BEZERRA, P. Problemas da poética em Dostoiévski. Rio de Janeiro: Forense Universitária, 2008. 
BARROS, D. L. P.; FIORIN, J. L. Dialogismo, polifonia e intertextulaidade. São Paulo: Editora da Universidade de São Paulo, 1999.

BEEVOR, A. A batalha pela Espanha: a Guerra Civil espanhola (1936-1939). Tradução de Maria Beatriz de Medina. $2^{a}$ ed. Rio de Janeiro: Record Ltda, 2007.

BUADES, J. Ma. Os espanhóis. São Paulo: Contexto, 2006.

CALDERÓN DE LA BARCA, P. El gran teatro del mundo. Auto Sacramental. Barcelona: Red Ediciones SL, 2019.

COLMEIRO, J. F. Memoria historica e identidad cultural. De la postguerra a la postmodernidad. Barcelona: Anthropos, 2005.

GARCÍA OCHOA, S. El coche como metáfora de la relación de pareja en el cine de Carlos Saura. Revista de Arte, no 97, p. 193-212, 2008. Disponível em: http://revpubli.unileon.es/index.php/dearte/article/view/1421 Acesso em: 09 junho 2018.

GARCILASO DE LA VEGA. Poesía castellana completa. Edição de Consuelo Burell. Madrid: Cátedra, 2003.

GENETTE, G. Palimpsestos: literatura en segundo grado. Trad. Célia Fernández Prieto. Madrid: Taurus, 1989.

GRACIÁN, B. El Criticón. Edición de Santos Alonso. Madrid: Cátedra, 2004.

HAMMERSCHMIDT, C. Espectrología o La escritura intermedial de Julio Llamazares [On line]. $I^{\circ}$ Congreso Internacional de Literatura y Cultura Españolas Contemporáneas, 1 al 3 de octubre de 2008, La Plata. Los siglos XX y XXI. Disponível em: http://www.memoria.fahce.unlp.edu.ar/trab eventos/ev.319/ev.319.pdf Acesso em: 29 abril 2019

KRISTEVA, J. História da linguagem. Tradução de Maria Margarida Barahona. Porto: Edições 70, 1999.

LLAMAZARES, J. La lluvia amarilla. Barcelona: Seix Barral, 2001.

MIRANDA POZA, J. A. El léxico de germanía en Rinconete y Cortadillo. Anuario de la Universidad Internacional SEK, nº 5, p. 237-249, 1999.

MIRANDA POZA, J.A. La alegoría como recurso retórico e ideológico en el medioevo: la Introducción a los Milagros de Berceo y la Cárcel de Amor, de Diego de San Pedro. In: LIMA, Aldo (org.) A propósito da metáfora. Recife: Editora Universitária da UFPE, 2014, p. 163192.

NOGUEIRA, S. R. Os signos da representação teatral: Calderón de la Barca (2002). Disponível

em: 
http://www.proceedings.scielo.br/scielo.php?pid=MSC0000000012002000200041\&script=s ci arttext Acesso em: 29 abril 2019.

RICOEUR, P. La metáfora viva. Madrid: Ediciones Cristiandad, 2001.

RUIZ VEGA, F. A. Goya en el cine de Carlos Saura. Alazet, 11, p. 73-97, 1999. Disponível em: https://dialnet.unirioja.es/servlet/articulo?codigo=127541 Acesso em: 29 abril 2019.

SÁNCHEZ VIDAL, A. El cine de Carlos Saura. Zaragoza: Caja de Ahorros de la Inmaculada, 1988.

SAURA, C. Elisa, vida mía. [Filme] (1977). Disponível em: https://www.utorrent.com/intl/pt/downloads/win

SAURA, C. Elisa, vida mía. Barcelona: Galaxia Gutemberg / Círculo de Lectores, 2004.

WEINRICH, H. Lete: arte e crítica do esquecimento. Tradução de Lya Luft. Rio de Janeiro: Civilização Brasileira, 2001.

i Professora do Departamento de Letras e Artes da Universidade Estadual da Paraíba, Campina Grande (PB) cristinauepb1@gmail.com

ii Professor do Programa de Pós-Graduação em Letras da Universidade Federal de Pernambuco, Recife (PE) ampoza@globo.com 